УДК 615.014

ББК 52.8

\title{
WAYS OF REGULATION OF RELEASE OF MEDICINAL SUBSTANCES FROM THE CHITOSAN FILMS ${ }^{1}$
}

\author{
Kulish Elena Ivanovna \\ Doctor of Chemical Sciences, Associate Professor, \\ Department of High-Molecular Compounds and Chemical Engineering, Bashkir State University \\ alenakulish@rambler.ru \\ Zaki Validi St., 32, 450076 Ufa, Russian Federation
}

\section{Shurshina Anzhela Samatovna}

Postgraduate Student, Department of High-Molecular Compounds and Chemical Engineering, Bashkir State University alenakulish@rambler.ru Zaki Validi St., 32, 450076 Ufa, Russian Federation

\section{Pearce Eli M.}

$\mathrm{PhD}$, Professor, Brooklyn Branch of New York University epearce@poly.edu Jay St., 300, Brooklyn, NY, USA

Abstract. The article studies the chitosan films obtained by applying acetic acid and two antibiotics of cephalosporin and aminoglycoside type. It investigates the possibility of their transport properties regulation in the sphere of medicines manufacture. This regulation can be carried out by films with thermal modification implying the heating of formed films at the temperature of about $120{ }^{\circ} \mathrm{C}$ and reaction with sodium dodecyl sulphate. The article shows that the antibiotics release from films will be determined by the amount of antibiotics connected with chitosan by \pm hydrogen bonds, on the one hand, and by the state of the polymer matrix, on the other hand.

Key words: chitosan, modification, medicines manufacture, polymer matrix, films.

\section{Introduction}

Systems with controlled transport of medicines are extremely demanded. The main task of antibacterial chemical therapy is the selective suppression of microorganisms without damaging the organism as a whole. The decrease of the antibiotics therapy efficiency observed recently, is mainly caused by the possibility of origination of bacteria strain tolerant (resistant) to these antibiotics. Polymer derivatives of (2) antibiotics can help to solve this task. We've made an attempt to use chitosan as a carrier of antibacterial preparations. In this situation the choice of chitosan (ChT) as a polymer carrier of a medicinal preparation is not accidental because this polymer possesses a whole spectrum of unique properties making it indispensable in polymer medicine [4]. In the present study we've considered some approaches to creating antibacterial ChT-based coatings of prolonged action suitable for treating surgical, burning and slowly-healing wounds of different etiology. 


\section{Experimentals}

The objects of investigation were a ChT specimen produced by the company "Bioprogress" (Russia) and obtained by acetic deacetylation of crab chitin and antibiotics both of cephalosporin series - cephazolin sodium salt (CPhZ), cephotoxim sodium salt (CPhT), and of aminoglycoside series amikacin sulfate (AMS), gentamicin sulfate (GMS). The investigation of the interaction of medicinal preparations with ChT was carried out according to the techniques described in $[1 ; 2]$.

ChT films were obtained by means of casting the polymer solution in acetic acid onto the glass surface with the formation of chitosan acetate (ChTA). The polymer mass concentration in the initial solution was $2 \mathrm{~g} / \mathrm{dl}$. The acetic acid concentration in the solution was 1,10 and $70 \mathrm{~g} / \mathrm{dl}$. Aqueous antibiotic solution was added to the ChT solution immediately before films formation. The content of the medicinal preparation in the films was $0.1 \mathrm{~mol} / \mathrm{mol} \mathrm{ChT}$. The film thickness in all the experiments was maintained constant and equal to $0.1 \mathrm{~mm}$. The kinetics of antibiotics release from ChT film specimens into aqueous medium was studied spectrophotometrically at the wave length corresponding to the maximum absorption of the medicinal preparation.

In order to regulate the ChT ability to be dissolved in water the anion nature was varied during obtaining $\mathrm{ChT}$ salt forms. So, a ChT-CPhZ film is completely soluble in water. The addition of aqueous sodium sulfate solution in the amount of $0.2 \mathrm{~mol} / \mathrm{mol} \mathrm{ChT} \mathrm{to} \mathrm{the} \mathrm{ChT-CPhZ} \mathrm{solution}$ makes it possible to obtain an insoluble ChT$\mathrm{CPhZ}-\mathrm{Na}_{2} \mathrm{SO}_{4}$ film. On the contrary, a ChT-AMS film being formed at the components ratio used in the process of work, isn't soluble in water. Obtaining a water-soluble film is possible if amikacin sulfate is transformed into amikacin chloride (AMCh). In this case the obtained ChTAMCh film will be completely soluble in water. Thus, the following film specimens have been analyzed in the investigation: $\mathrm{ChT}-\mathrm{CPhZ}$ and ChTCPhT (soluble forms); ChT-CPhZ-Na ${ }_{2} \mathrm{SO}_{4}$ (insoluble-in-water form); ChT-AMCh (soluble form); ChT-AMS and ChT-GMS (insoluble-inwater forms).

AlsotTo prevent solubility of the film in water chitosan film was subjected to thermal modification consisting in heating the formed film at the temperature of about $120{ }^{\circ} \mathrm{C}$ for 15 $200 \mathrm{~min}$ and it was treated with the solution of the surface-active substance - sodium dodecyl sulphate (SDS) with concentration equal to 1$15 \mathrm{~g} / \mathrm{dl}$.

With the aim of determining the amount of medicinal preparation held by the polymer matrix there was carried out the synthesis of adducts of the ChT-antibiotic interaction in the mole ratio $1: 1$ in acetic acid solution. The synthesized adducts were isolated by double reprecipitation of the reaction solution in $\mathrm{NaOH}$ solution with the following washing of precipitated complex residue with isopropyl alcohol. Then the residue was dried in vacuum up to constant mass. The amount of preparation strongly held by chitosan matrix was determined according to the data of the element analysis on the analyzer EUKOEA-3000.

IR spectra of specimens were recorded on the spectrometer "Specord M80" and "Shimadzu" (KBr tablets, films) in the area of $700-3600 \mathrm{sm}^{-1}$. UV spectra of all specimens were taken in quarts dishes with thickness of $1 \mathrm{sm}$ relative to water on the spectrophotometer "Specord M40" in the area of 220-350 nm.

\section{The results discussion}

On the basis of the chemical structure of the studied medicinal compounds [3] one can suggest that they are able to combine with ChT forming polymer adducts of two types - ChTantibiotics complexes and polymer salts produced due to the exchange interaction. As a result, some quantity of medicinal substance will be held in the polymer chain. The interaction taking place between the studied medicinal compounds and ChT was demonstrated by UV- and IRspectroscopy data.

The interaction of antibiotics with $\mathrm{ChT}$ is evidenced by UV spectroscopic data. The maximum absorption of $\mathrm{CPhZ}$ and $\mathrm{CPhT}$ at its concentration of $10^{-5} \mathrm{M}$ in $1 \%$ acetic acid is observed at 273 and $261 \mathrm{~nm}$, respectively. Upon addition of equivalent amount of ChT to the solution, the intensity of the absorption peak of the medicinal preparation noticeably grows and its position is bathochromically shifted by approximately 5-10 $\mathrm{nm}$. The UV spectrum of AMS and GMS at a concentration of $10^{-2} \mathrm{M}$ in 
$1 \%$ acetic acid shows an absorption peak at 267 and $286 \mathrm{~nm}$, respectively. Addition of a ChT solution to the solution of medicinal substances results in that a precipitate is formed; however, analysis of the supernatant fluid shows that the peak of the corresponding absorption band in its spectrum is shifted by $5-7 \mathrm{~nm}$. The observed changes unambiguously indicate that $\mathrm{ChT}$ affects the electron system of MS and adducts are formed. The binding energies in the complexes, evaluated by the shift of the absorption peaks in the UV spectra, are about $10 \mathrm{~kJ} \mathrm{~mol}^{-1}$. This suggests that the complexation occurs via hydrogen bonds.

The interaction of the antibiotics under study with ChT is also confirmed by IR spectroscopic data. For example, the IR spectrum of ChT shows absorption bands at 1640 and $1560 \mathrm{~cm}^{-1}$, associated with deformation vibrations of the acetamide and amino groups, and at 1458 and $1210 \mathrm{~cm}^{-1}$, associated with planar deformation vibrations of hydroxy groups. Analysis of the IR spectra of adducts formed by interaction of ChT with antibiotics suggests that some changes occur in the IR spectra. For example, absorption bands associated with stretching vibrations of the $\mathrm{C}=\mathrm{O}$ and $\mathrm{C}=\mathrm{N}$ groups of the medicinal compound appear at 1750 and $1710 \mathrm{~cm}^{-1}$ in the IR spectra of ChT-CPhZ polymeric adducts, and a strong absorption band related to the $\mathrm{SO}_{4}{ }^{2-}$ group appears at $619 \mathrm{~cm}^{-1}$ in the IR spectrum of the CTS-AMS reaction product. In addition, the IR spectra of all the compounds being analyzed show that the absorption band at $3000-3500 \mathrm{~cm}^{-1}$, associated with stretching vibrations of $\mathrm{OH}$ and NH groups, is broadened as compared with the corresponding bands of the antibiotics and $\mathrm{ChT}$, which, taken together, suggests that ChT-antibiotic complex compounds are formed via hydrogen bonds.

Table 1 gives the data on the amount of antibiotics determined in polymer adducts obtained from acetic acid solution.

Attention should be paid to the fact that the amount of medicinal preparation in the adduct of the ChT-medicinal preparation reaction is considerably higher in the case of antibiotics of aminoglycoside series than in the case of antibiotics of cephalosporin series. This can be connected with the fact that $\mathrm{CPhZ}$ and $\mathrm{CPhT}$ anions interact with ChT polycation forming salts readily soluble in water. In the case of using AMS and GMS because of two-base character of sulphuric acid one may anticipate the formation of water-insoluble "double" salts ChT-AM or ChT-GM sulfates due to which additional quantity of antibiotics is held on the polymer chain.

Table 2 gives the data on the value of the rate of AMS and GMS release from film specimens formed from acetic acid solutions of different concentrations. The rate was evaluated only for water-insoluble films because at using soluble films the antibiotic release was determined not by medicinal preparation diffusion from swollen matrix but by film dissolving.

Attention must be given to the fact of interaction between the rate of antibiotics release from chitosan films and their amount which is strongly held in ChT chain. For example, at increasing the concentration of acetic acid used as a solvent the amount of medicinal preparation connected with the polymer chain decreases in all the cases considered by us. Correspondingly, the rate of antibiotics release from films insoluble in water, increases.

The influence of the amount of medicinal preparation strongly held in ChT matrix, on the rate of medicinal substance release from the film must be most pronounced at comparing the rates of release of antibiotics of aminoglycoside series and cephalosporin one. However, ChT$\mathrm{CPhZ}$ and ChT-CPhT films are soluble in water while ChT-AMS and ChT-GMS ones do not dissolve in water and it isn't correct to compare them. At ChT transition into insoluble form (by adding sodium sulfate) the rate of release of antibiotics of cephalosporin series decreases considerably (Fig. 1, curve 1) as compared with a soluble form but still it is higher than that in the case of antibiotics of aminoglycoside series (Fig. 1, curve 2). It should be also noted that the rate of antibiotics release from soluble ChT$\mathrm{CPhZ}$ film (Fig. 1, curve 3) is also higher than in the case of ChT-AMCh film (Fig. 1, curve 4). Thus, considerable difference between the rate of release of aminoglycoside series antibiotics and that of cephalosporin series antibiotics is evidently explained by the difference in the amount of ChT-antibiotics adduct. 
The amount of antibiotics determined in reaction adducts

\begin{tabular}{|c|c|c|}
\hline $\begin{array}{l}\mathrm{C}_{\mathrm{CH}_{3} \mathrm{COOH}, \mathrm{g} / \mathrm{dl}} \\
\text { in the initial solution }\end{array}$ & The antibiotics used & $\begin{array}{l}\text { The amount of antibiotics } \\
\text { in reaction adduct, \% mass }\end{array}$ \\
\hline \multirow[t]{4}{*}{1} & $\mathrm{CPhZ}$ & 10,10 \\
\hline & $\mathrm{CPhT}$ & 15,90 \\
\hline & AMS & 61,50 \\
\hline & GMS & 59,40 \\
\hline \multirow[t]{4}{*}{10} & $\mathrm{CPhZ}$ & 5,88 \\
\hline & $\mathrm{CPhT}$ & 57,50 \\
\hline & AMS & 55,80 \\
\hline & GMS & 31,30 \\
\hline \multirow[t]{4}{*}{70} & $\mathrm{CPhZ}$ & 3,03 \\
\hline & $\mathrm{CPhT}$ & 3,70 \\
\hline & AMS & 41,30 \\
\hline & GMS & 40,10 \\
\hline
\end{tabular}

Table 2

Transport properties of chitosan films in relation to medicinal preparation release

\begin{tabular}{|c|c|c|}
\hline $\begin{array}{c}\text { Acetic acid } \\
\text { concentration } \mathrm{g} / \mathrm{dl}\end{array}$ & The antibiotics used & Release, \% mass $/ \mathrm{h}$ for chitosan specimens \\
\hline \multirow{2}{*}{1} & AMS & 0,5 \\
\cline { 2 - 3 } & GMS & 0,4 \\
\hline \multirow{2}{*}{10} & AMS & 0,8 \\
\cline { 2 - 3 } & GMS & 0,5 \\
\hline \multirow{2}{*}{70} & AMS & 1,5 \\
\cline { 2 - 3 } & GMS & 1,3 \\
\hline
\end{tabular}

Thus, at forming film coatings one should proceed from the fact that a medicinal preparation can be distributed in the polymer matrix in two ways. One part of it connected with polymer chain, for example, by complex formation is rather strongly held in that polymer chain. The rest of it is concentrated in polymer free volume (in polymer pores). The rate of release of antibiotics from the film will be determined by the amount of antibiotics connected with ChT by hydrogen bonds, on the one hand, and by the state of the polymer matrix including its ability to dissolve in water, on the other hand.

In essential decrease of affinity of a film to water results the heat treatment of films which is accompanied by removing acetic acid bond by aminogroups and can result in the amidation process with chitosan units formation. The fact of formation of amide groups in heated films is confirmed by considerable strengthening of amide I band in IRspectra in the area $1630-1550 \mathrm{sm}^{-1}$. Besides, one can observe the decrease in intensity of absorption of stretching vibrations of hydroxyl groups and the appearance of the shoulder characteristic of stretching vibrations of aminogroups, in the area $3500-3000 \mathrm{sm}^{-1}$. These data testify to the fact that at heating there really occurs the increase both in the depth of the amidation reaction and in the splitting out of acetic acid.

Since the heat treatment of films results in the loss of solubility in water the increased time of thermal treatment hinders the liberation of antibiotics from polymer matrix and, consequently, decreases the rate of medicinal substances release from films. By varying the thermal treatment 


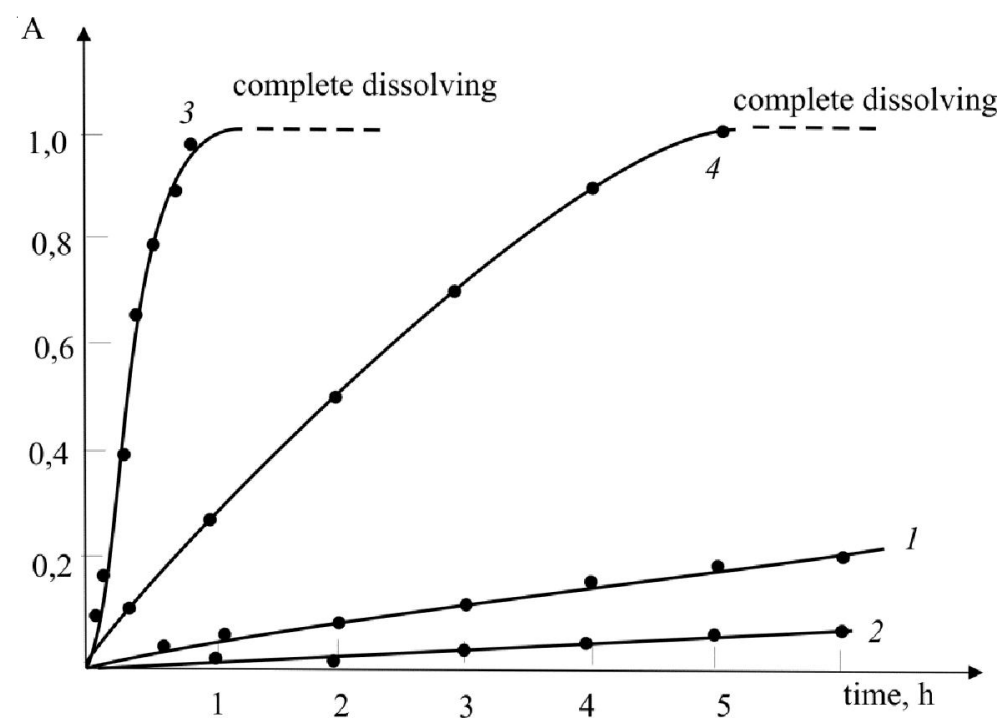

Fig. 1. The kinetic curve of the release of $\operatorname{CPhZ}(1,3)$ and $\operatorname{AM}(2,4)$ from insoluble $(1,2)$ and soluble $(3,4)$ films

conditions it is possible to vary the transport properties of films as well.

Thermally modified films behave in a different way-considerable slowing the release of medicinal substance from the film takes place. During the first 10-20 hours there occurs the release of medicinal preparation at constant rate, then the process slows down and on the $7-10^{\text {th }}$ day the concentration of the medicinal substance in the aqueous phase reaches its constant value. As this takes place, the longer is the period of subjecting the film to thermal treatment, the lower are the rate and the ultimate yield of antibiotic from the film (Fig. 2, Table 1).

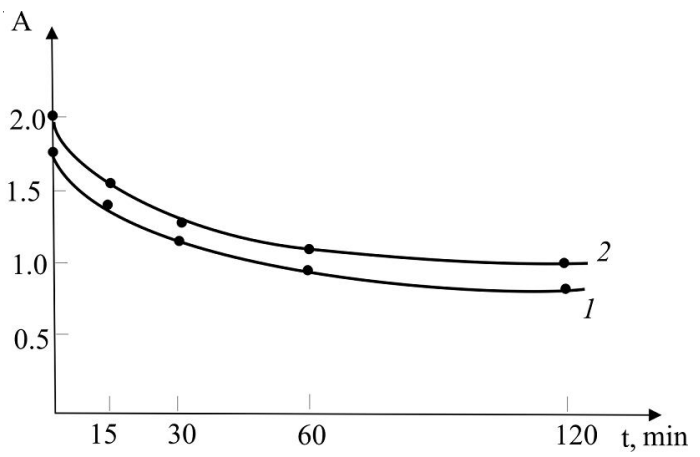

Fig. 2. The dependence of the value of solution optical density corresponding to the ultimate yield of $\mathrm{CPh}(1)$ and $\mathrm{CPhT}$ (2) from the films formed

in $1 \%$ acetic acid, on the time of the film heat treatment
Regulation the rate and degree of the medicinal substance release from polymer matrix can be also done through a modification of the obtained films by treatment of its surface-active substance - sodium dodecyl sulphate. As well as in case of the haet treatment films, the rate of medicinal substances from the films modified SAS occurs much slower. In this case the longer the film was being treated with SAS and the higher was its concentration, the lower is the release rate and the ultimate antibiotic yield from the film (Table 3 ). It is evident that the use of micellar SDS solution for films modification results in the formation of a strong water-insoluble SAS polyelectrolitic complex. The surface of the modified film in this case represents a semi-penetrable membrane which allows water to penetrate into the film. The increase of the inner layer volume leads to the surface membrane extention and the release of the medicinal substance from the film is facilitated. In this case, the higher is the concentration of SDS used for modification and the longer is the time of the film holding in SAS solution, the thicker is the semi-penetrable membrane and the less is the medicinal preparation yield from the film (Fig. 3, 4). 
The influence of conditions of chitosan films obtaining and modification on transport properties of these films (initial rate and ultimate yield of antibiotics from a film)

\begin{tabular}{|c|c|c|c|c|c|}
\hline $\begin{array}{l}\text { Anti- } \\
\text { biotic }\end{array}$ & \multicolumn{2}{|c|}{ Way of modification } & $\begin{array}{c}\text { Treatment time, } \\
\text { min }\end{array}$ & Initial rate, $Q^{*} / \mathrm{h}$ & $\begin{array}{l}\text { Ultimate } \\
\text { yield, Q * }\end{array}$ \\
\hline \multirow[t]{9}{*}{$\mathrm{CPhZ}$} & \multirow{4}{*}{\multicolumn{2}{|c|}{ heat treatment }} & 15 & 2.80 & 80 \\
\hline & & & 30 & 2.55 & 76 \\
\hline & & & 60 & 2.20 & 65 \\
\hline & & & 120 & 2.00 & 57 \\
\hline & \multirow{5}{*}{$\begin{array}{l}\text { treatment } \\
\text { with the solution } \\
\text { of SAS }\end{array}$} & \multirow[t]{3}{*}{$5 \%$ mass } & 15 & 2.70 & 82 \\
\hline & & & 30 & 2.55 & 70 \\
\hline & & & 60 & 2.25 & 58 \\
\hline & & $10 \%$ mass & 30 & 2.40 & 56 \\
\hline & & $15 \%$ mass & 30 & 2.30 & 52 \\
\hline \multirow[t]{9}{*}{$\mathrm{CPhT}$} & \multirow{4}{*}{\multicolumn{2}{|c|}{ heat treatment }} & 15 & 2.85 & 81 \\
\hline & & & 30 & 2.60 & 77 \\
\hline & & & 60 & 2.20 & 64 \\
\hline & & & 120 & 2.0 & 56 \\
\hline & \multirow{5}{*}{$\begin{array}{c}\text { treatment } \\
\text { with the solution } \\
\text { of SAS }\end{array}$} & \multirow[t]{3}{*}{$5 \%$ mass } & 15 & 2.60 & 80 \\
\hline & & & 30 & 2.50 & 68 \\
\hline & & & 60 & 2.30 & 58 \\
\hline & & $10 \%$ mass & 30 & 2.45 & 54 \\
\hline & & $15 \%$ mass & 30 & 2.25 & 50 \\
\hline
\end{tabular}

Q* $\%$ mass $\mathrm{CPhZ}$ of its initial amount introduced into the film.

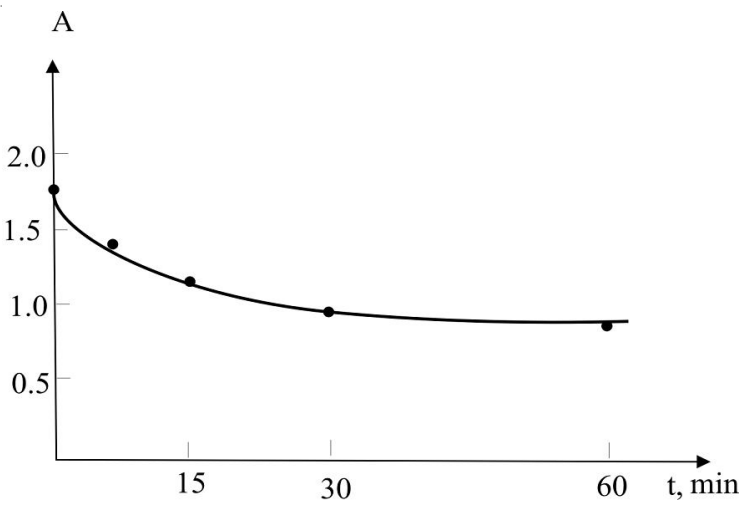

Fig. 3. The dependence of the solution optical density value corresponding to the ultimate $\mathrm{CPhZ}$ yield from the films formed in $1 \%$ acetic acid, on the time of films treating in $5 \%$ SDS solution

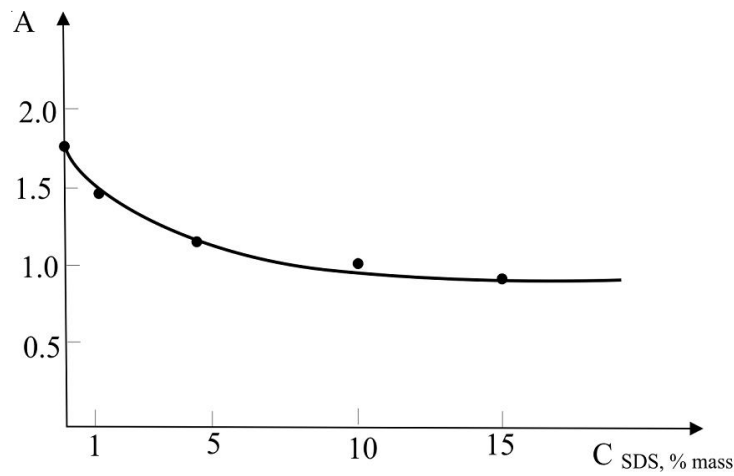

Fig. 4. The dependence of the solution optical density value corresponding to the ultimate $\mathrm{CPhZ}$ yield from the films formed in $1 \%$ acetic acid and treated with SAS solution for $30 \mathrm{~min}$, on SDS concentration 


\section{ТЕХНИКО-ТЕХНОЛОГИЧЕСКИЕ ИННОВАЦИИ}

Thus, this ways allow to regulate the degree and rate of medicinal substance release from polymer matrix.

\section{Conclusions}

Thus, ChT transfer in a insoluble form allows to get film antibacterial coverings with the prolonged exit of medicine which are deprived of the problems arising at use of individual antibiotics.

Essentially important fact is that eventually in all studied cases of change in a range of absorption are observed not with a length of the wave corresponding to absorption of an individual antibiotic, and with a length of the wave corresponding to absorption of a polymeric complex. It means, that even in case when the formed film is formally insoluble in water, after all passes ChT quantity into a water phase, it forms a complex, with an antibiotic allocated from a film. Thus, it is possible to believe that anyway on a wound surface formation of "polymeric medicine"-ChT-medicinal substance is possible.

\section{NOTES}

${ }^{1}$ This work was supported by The Ministry of Education and Science of the Russian Federation on the subject "Development of physical and chemical bases of creating new polymeric materials of biomedical appointment with controlled sorption, rheological and structural and physical characteristics on the basis of natural and synthetic polymers".

Работа выполнена при финансовой поддержке Минобрнауки РФ по теме «Разработка физико-химических основ создания новых полимерных материалов биомедицинского назначения с контролируемыми сорбционными, реологическими и структурно-физическими характеристиками на основе природных и синтетических полимеров».

\section{REFENCES}

1. Mudarisova R.Kh., Kulish E.I., Kolesov S.V., Monakov Yu.B. Investigation of Chitosan Interaction with Cephazolin. JACh., 2009, vol. 82, no. 5, pp. 347-349.

2. Mudarisova R.Kh., Kulish E.I., Ershova N.R., Kolesov S.V., Monakov Yu.B. The Study of Complex Formation of Chitosan with Antibiotics Amicacin and Hentamicin. JACh., 2010, vol. 83, no. 6, pp. 1006-1008.

3. Mashkovsky M.D. Medicinal Preparations. Vol. 2. Kharkov, Torsing Publ., 1997. 278 p.

4. Skryabin K.G., Vikhoreva G.A., Varlamov V.P. Chitin and Chitosan. Obtaining, Properties and Application. Moskow, Nauka Publ., 2002. 365 p.

\section{СПОСОБЫ ПРОИЗВОДСТВА ЛЕКАРСТВЕННЫХ ВЕЩЕСТВ ИЗ ПЛЕНОК ХИТОЗАНА}

\section{Кулиш Елена Ивановна}

Доктор химических наук, доцент,

профессор кафедры высокомолекулярных соединений и химической технологии

Башкирского государственного университета

alenakulish@rambler.ru

ул. Заки Валиди, 32, 450076 г. Уфа, Российская Федерация

\section{Шуршина Анжела Саматовна}

Аспирант кафедры высокомолекулярных соединений и химической технологии

Башкирского государственного университета

alenakulish@rambler.ru

ул. Заки Валиди, 32, 450076 г. Уфа, Российская Федерация 


\section{Пирс Элай М.}

Доктор наук, профессор Бруклинского филиала Нью-Йоркского университета epearce@poly.edu Jay St., 300, Бруклин, Нью-Йорк, США

Аннотация. В работе были исследованы пленки хитозана, полученные с помощью уксусной кислоты и содержащий два антибиотика из рядов цефалоспорина и аминогликозида, была изучена возможность регулирования их транспортных свойств в отношении лекарственного выпуска. Это регулирование может быть выполнено пленками с термической модификацией, состоящей в нагревании сформированных пленок при температуре приблизительно $120^{\circ} \mathrm{C}$ и взаимодействия с sodium dodecyl sulphate. Было показано, что выпуск антибиотиков из пленок будет определен количеством антибиотиков, связанных с хитозаном водородными связями, с одной стороны, и устройством матрицы полимера, с другой.

Ключевые слова: хитозан, модификация, производство лекарств, матрица полимера, пленки. 